\title{
Estimates for Carbon Stocks in Soil under Humid Grassland Areas in the Federal District of Brazil
}

\author{
Andreia M. S. França' ${ }^{1}$, Rodrigo J. O. Paiva², Edson E. Sano ${ }^{3}$, Arminda M. Carvalho ${ }^{3}$ \\ ${ }^{1}$ Instituto Federal de Brasília, Campus Samambaia, Brasilia, Brazil \\ ${ }^{2}$ Universidade de Brasília, Pós-Graduação em Geoprocessamento Ambiental, Brasilia, Brazil \\ ${ }^{3}$ Empresa Brasileira de Pesquisa Agropecuária, EMBRAPA Cerrados, Brasilia, Brazil \\ Email: andreia.franca@ifb.edu.br
}

Received 18 July 2014; revised 18 August 2014; accepted 25 August 2014

Copyright (C) 2014 by authors and Scientific Research Publishing Inc.

This work is licensed under the Creative Commons Attribution International License (CC BY). http://creativecommons.org/licenses/by/4.0/

(c) (i) Open Access

\section{Abstract}

The soils that lay below humid ecosystems are characterized as being significant holders of carbon. Because of the great susceptibility of this type of environment to anthropic changes, expressive quantities of carbon stored in the soil can be released into the atmosphere. In the Cerrado biome (Brazil), only a few types of vegetation have had carbon storage levels in their soil estimated. The main purpose of this study was to obtain basic quantitative parameters for carbon storage and to identify the general aspects of soil in regions where there exists Humid Grasslands (Campo Limpo Úmido), a kind of humid area phytophysiognomy found in the Cerrado. We selected 6 regions of the Federal District with this kind of vegetation formation, characterized by low anthropic impact and located either in the interior or in the proximity of specially protected areas. In each one of the sampled regions, we marked a transect with 4 equidistant points and collected material at 7 different levels of depth: $0-5,5-10,10-20,20-30,30-40,40-50$ and $50-60 \mathrm{~cm}$. We obtained 168 samples, with 84 related to Humid Grassland areas in gleysols and 84 samples related to areas in plinthosols-types of soil dominant in this environment. We determined the texture, bulk density and concentration of nitrogen and carbon at each depth. The average concentration of carbon for Humid Grassland areas was $55.19 \mathrm{~g} \cdot \mathrm{kg}^{-1}$, with an average of $61.65 \mathrm{~g} \cdot \mathrm{kg}^{-1}$ for Gleysols and $48.73 \mathrm{~g} \cdot \mathrm{kg}^{-1}$ for Plinthosols. The soil samples displayed distinct textural differences between gleysols and plinthosols. There were no significant differences in soil density $(0.75$ $\mathrm{kg} \cdot \mathrm{dm}^{-3}$ for Gleysols and $0.72 \mathrm{~kg} \cdot \mathrm{dm}^{-3}$ for Plinthosols). The average concentration of nitrogen was $20.66 \mathrm{~g} \cdot \mathrm{kg}^{-1}$, with $23.98 \mathrm{~g} \cdot \mathrm{kg}^{-1}$ for Gleysols and $17.34 \mathrm{~g} \cdot \mathrm{kg}^{-1}$ for Plinthosols. The average carbon storage for Humid Grassland areas, down to $60 \mathrm{~cm}$ deep, was $244.17 \mathrm{mg} \mathrm{C}^{-1}$ and the total estimated stock for these areas in the Federal District was $206.71 \mathrm{Gg} \cdot \mathrm{C}$. In general, the samples obtained in gleysols showed a carbon content and nitrogen level superior to those in plinthosols, although a greater sampling effort is needed to confirm the differences observed. The density values 
of stored carbon in the soil beneath Humid Grassland areas proved to be superior to those values observed for other types of vegetation typical for the Cerrado environment.

\title{
Keywords
}

\author{
Cerrado, Wetland, Carbon Stocks, Grasslands
}

\section{Introduction}

The increase of greenhouse-gas concentration (GGC) $-\mathrm{CO}_{2}, \mathrm{~N}_{2} \mathrm{O}$ and $\mathrm{CH}_{4}-$ within the earth's atmosphere, as well as its direct effect on climate change, makes the study of these elements impact on the environment extremely important, especially carbon, which, compared to other GGCs, is emitted in greater quantities due to the burning of fossil fuels, deforestation and others [1].

Soils are an important player in carbon's biogeochemical cycle - they can store around four times more carbon than vegetal biomass and almost three times more than the atmosphere [2]. Carbon dioxide is produced in the soil by microorganisms, roots and by the oxidation of carbon-filled material. Its emission into the atmosphere is known as soil respiration or soil $\mathrm{CO}_{2}$ efflux. On a global scale, this process in soil accounts for the release of around $78 \pm 12 \mathrm{Pg} \mathrm{C}$, while the burning of fossil fuels accounts for the liberation of $270 \pm 30 \mathrm{Pg} \mathrm{C}$ [3]. A great amount of carbon stored in soil can be restored and, potentially, result in the sequestration of $0.9 \pm 0.3$ Pg C per year, around one third of the carbon emitted annually to the atmosphere [3]. A series of scientific works have been developed with the purpose of quantifying and understanding factors that control the dynamics of carbon storage in soil, and obtaining parameters that are essential for the use of mechanisms aimed at reducing content emission from soil to the atmosphere.

Activities resulting in a higher emission of carbon dioxide from soil to atmosphere are affected mainly by their physical aspects, such as increase in temperature, decrease in the water content and higher gas diffusivity [4]. The soils in wetland areas are usually kept in anaerobic conditions (low oxygen level, high quantity of water, low gas diffusivity) - factors that contribute to accumulation of organic matter [5]. Because of these aspects, soil under wetlands can be seen as important storage areas and potential sources for carbon liberation. Despite their importance, wetlands frequently suffer from hydrological changes, like the lowering of the water table, which derive from the conversion and drainage of regions for use in agriculture and animal husbandry [6]-[8]. The level of the water table sheet has important effects on $\mathrm{CO}_{2}$ emissions on these areas. Saturation of the soil restricts the diffusivity of atmospheric oxygen, lowering microbial activity and the rate of decomposition [4] [5] [7]. Small differences in the climate, hydrology and the use of land can cause significant changes to the delicate balance that exists with carbon stored in the soil of tropical wetland regions [6].

In Brazil, natural areas of considerable size have been subjected to anthropic conversion in order to provide space for the creation of areas for cultivated pastures, annual crops and reforestation. Among the Brazilian biomes the Cerrado (a biome with typical savanna formation) is the one with the largest absolute area of deforestation, in addition to having the highest rate of current conversion and the biggest potential for future conversion [9]-[14]. A great diversity of vegetation is also typical to the Cerrado, creating a mosaic of different phytophysiognomies. Although most of Cerrado vegetation is associated with well-drained soil, this biome also possesses types of vegetation that experience periodic flooding that corresponds with wetland ecosystems [15] [16].

Among these physiognomies, Humid Grasslands (Campo Limpo Úmido) are characterized by the predominance of a continuous herbaceous extract and the absence of trees or bushes in addition to a great abundance of species from the Poaceae family [17]. Humid grasslands are found wherever the water table is superficial, especially in riverbed areas, on slopes, at the bottom of valleys and bordering gallery forests, in hydromorphic soil [16].

Our aim in this study, considering the potential importance of Humid Grassland vegetation for maintaining carbon in the soil and for inhibiting its release into the atmosphere, is to obtain basic quantitative parameters for carbon storage and to identify general aspects of the soil in regions where these conditions exist. The results of our study will be utilized in the eventual development and application of mechanisms designed to reduce carbon emission. 


\section{Methods}

\subsection{Study Area}

The study was conducted in the Federal District of Brazil, which occupies $5779 \mathrm{~km}^{2}$ located in the central region of the Cerrado, around $0.3 \%$ of the total area of this Biome $\left(2.03\right.$ million $\left.\mathrm{km}^{2}\right)$ [18]. This region is a typical Cerrado environment, with a heterogeneous mosaic of vegetation [15] [19]-[21]. The dominant native vegetation is dense savanna, but open savanna, gallery forests, deciduous forests, and grasslands are also found. Most of the natural landscape in this region is characterized by well-drained plains and plateaus, with sparse occurrences of poorly drained lands [19]. The region has a humid tropical climate (Aw-Köppen system), characterized by a distinct seasonality, with dry winters and rainy summers. Around $70 \%$ of the Federal District area is occupied by regions of anthropic use class [9], with most of the well-preserved natural areas located on public property and reserved for conservation of the natural environment and research, and the protection of water resources.

Humid Grasslands areas are usually found in horizontal stripes along valley sides, separating the Cerrado senso stricto (dense savanna) from the Gallery Forest (Figure 1). In most cases, Humid Grasslands areas draw welldefined borders with these other kinds of vegetation in a region where abrupt transitions between different biological communities are common. The water tables in these regions tend to be shallow and frequently flow to the surface, and the large majority of time soils remain saturated with water.

The mapping of Humid Grassland areas in the Federal District was done by [22], using multi-spectral images-Landsat5/TM and CBERS2B/HRC. By using the Kappa index, they obtained $80 \%$ accuracy in the mapping. As a result, there was detection of $8.46 \mathrm{~km}^{2}$ of Humid Grassland in the Federal District (Figure 2).

\subsection{Soil Aspects}

The soils presented in the studied area were gleysols and plinthosols [23] (Figure 1(b) and Figure 1(c)). Gleysols are formed from alluvial sediments, with water tables near the surface for most of the year, making it an environment of cumulative organic matter and of organic oxidation [24]. They are soils that occasionally have a sandy texture (sand or loam) in superficial horizons, and followed by grey horizons of loam, or thinner texture [23] [25]. They are soils developed from unconsolidated material (sediment and saprolite) and heavily influenced by occurrences of prolonged flooding. Such conditions are usually induced by a water table near the surface that, at least in some months of the year, leaves the pores saturated with water for a relatively long time. This saturation, in the presence of organic matter, decreases dissolved oxygen and causes the dissolution and chemical reduction of iron oxides, which are transformed and partially removed. This results in grey colors appearing in sub superficial horizons [26].
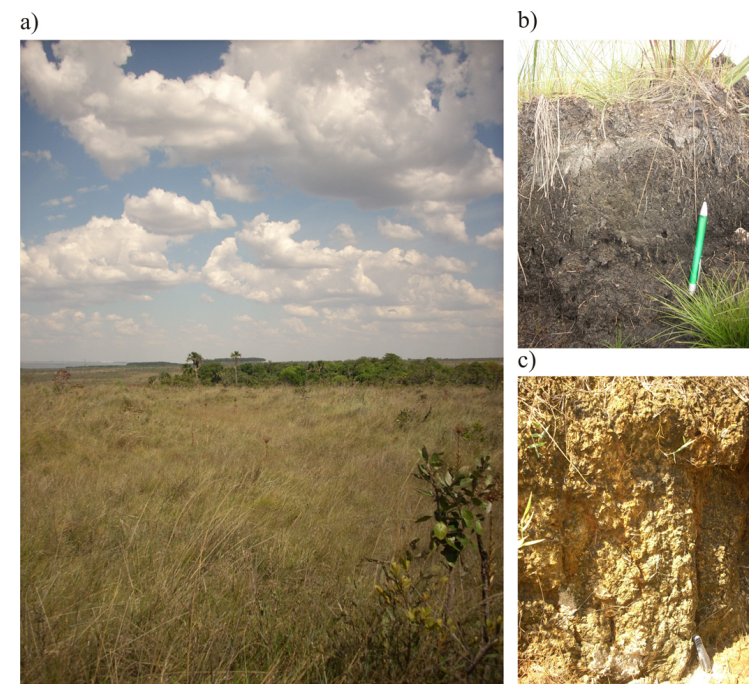

Figure 1. General aspects of a Humid Grassland during the dry season, its border with the gallery forest (a), aspect of gleysols (b), and plinthosols (c) in the study areas. 


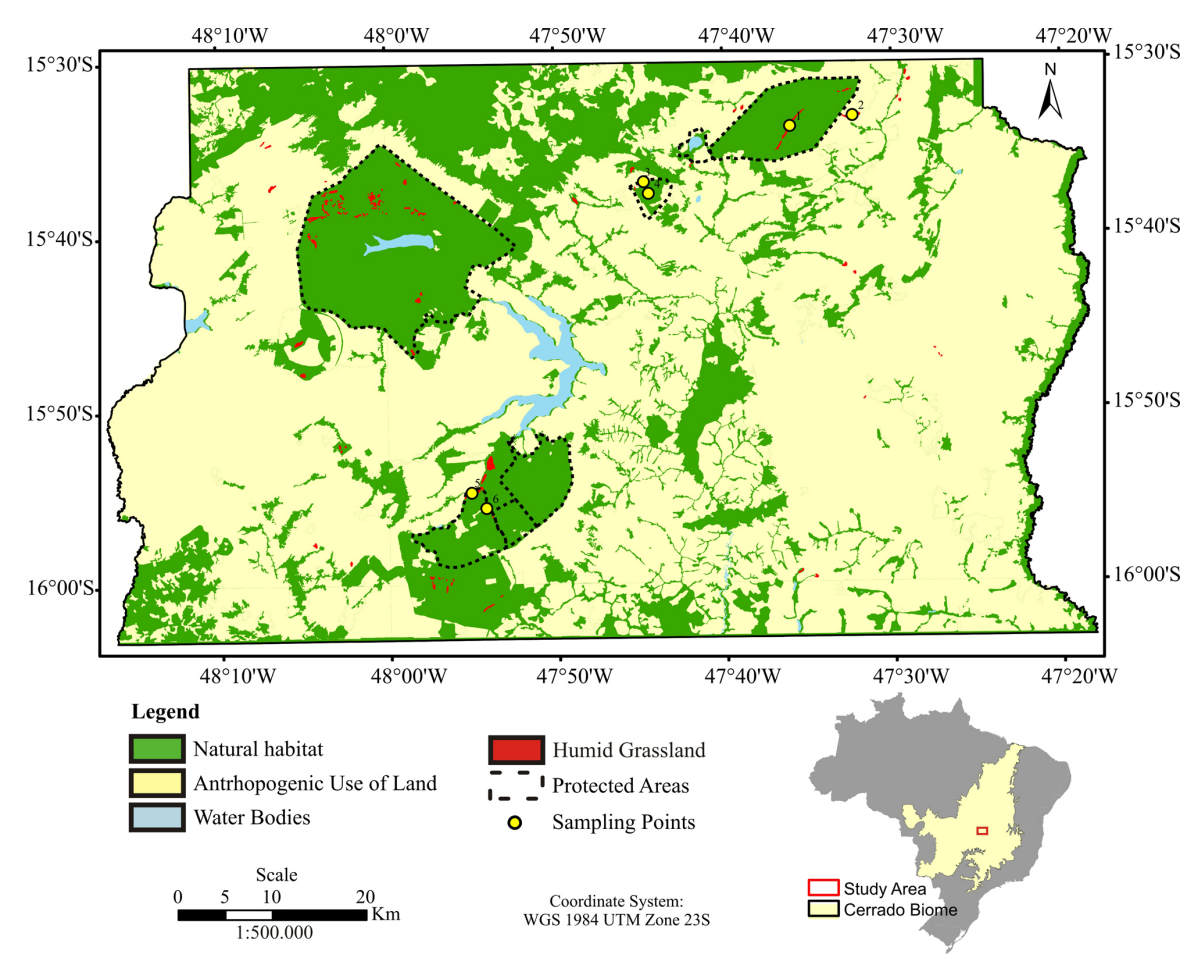

Figure 2. Localization of the sampling points and Humid Grassland areas in the Federal District: 1) and 2) Águas Emendadas Ecological Station (250 $\mathrm{km}^{2}$ Strict Protected Area); 3) and 4) Area for Protection of Corguinho's Water Sources (Area for Protection of Water Sources); 5) and 6) Água Limpa Farm (Research station owned by University of Brasília).

Plinthosols are related to hydromorphic mineral soils, with serious restriction to water percolation; they are also found in incidents of temporary flooding and, thus, slow draining [24]. Morphologically, they show a subsurface horizon with red stains spread in the profile, which has a variegated aspect (result of iron concentration in the soil), called plinthite [23] [25]. They are soils formed when conditions create some hindrance to gravitational water movement, especially in locals where there is a big oscillation in the water table, facilitating plinthite formation [26]. They appear in hot and wetland regions, especially in those with a well-defined dry season, or a period with a marked decrease in pluvial precipitation [27].

\subsection{Field Sampling}

In the region of interest, the interior proximities of specially protected areas, we selected six sampling areas with typical Humid Grasslands (Figure 2). In each one of the studied regions, we selected samples from both gleysol and plinthosol soil types (Table 1). These areas were selected based on the preservation of their natural aspects and low anthropic impact.

In each one of the six Humid Grasslands selected, a transect was delimited in the central region, beginning at the border of Cerrado sensu stricto and ending in the Gallery Forest, thus crossing the entire area. In each transect, 4 equidistant sampling points were marked where we collected samplings at seven different depths: 0 - 5 $\mathrm{cm}, 5-10 \mathrm{~cm}, 10-20 \mathrm{~cm}, 10-20 \mathrm{~cm}, 20-30 \mathrm{~cm}, 30-40 \mathrm{~cm}, 40-50 \mathrm{~cm}$ and $50-60 \mathrm{~cm}$. To determine the total organic carbon (TOC) and the texture of the soil we collected disturbed samples using a Dutch auger; to determine the bulk density, we collected undisturbed samples using volumetric rings. As a result, we obtained 168 samples, with 84 samples related to Humid Grassland areas under gleysols (12 samples in each depth) and 84 samples related to Humid Grassland areas under plinthosols (12 samples in each depth).

\subsection{Sample Analysis and Preparation}

The soil's textural aspects were ascertained for all the depth intervals using a grain size analysis of the disturbed samples. This method separated its fractions by classes according to their diameters: clay $(0.000-0.002 \mathrm{~mm})$, 
Table 1. Humid Grassland areas and the type of soil samples we collected from each (Figure 2).

\begin{tabular}{ccc}
\hline Point & Description & Soil Type \\
\hline 1 & Águas Emendadas Ecological Station-1 & Gleysol \\
2 & Águas Emendadas Ecological Station-2 & Plinthosol \\
3 & Area for Protection of Corguinho's Water Sources-1 & Gleysol \\
4 & Area for Protection of Corguinho's Water Sources-2 & Plinthosol \\
5 & Água Limpa Farm-UnB-1 & Gleysol \\
6 & Água Limpa Farm-UnB-2 & Plinthosol \\
\hline
\end{tabular}

silt $(0.002-0.063 \mathrm{~mm})$ and sand $(0.063-2 \mathrm{~mm})$.

The bulk density, on the other hand, was determined using undisturbed samples of soil at different depths using a steel ring with a sharp edge and internal capacity of $100 \mathrm{~cm}^{3}$. The samples obtained were dried in a greenhouse at $110^{\circ} \mathrm{C}$ and weighed using a precise scale. The bulk density (BD) was determined as a function of the mass of dry soil and of the known volume $(\mathrm{BD}=$ Mass/Volume).

The soil samples collected to determine the concentration of carbon and nitrogen were air-dried and later crushed and sieved through a $2 \mathrm{~mm}$ sifter. These samples were subsequently ground in a grinder with the use of mortar and pestle until the particles could pass through a $0.25 \mathrm{~mm}$ mesh sifter. All equipment (grinder, mortar, pestle and sifters) was sanitized before and after every exchange of the sampling group to avoid contamination. Sub-samples were weighted between 20 and $30 \mathrm{mg}$, with precision out to 4 decimal places, in tin capsules and submitted for analysis to determine the total $\mathrm{C}$ in the soil (TOC).

To determine the concentration of carbon and nitrogen in the soil, we employed the dry combustion analytical method, to $900^{\circ} \mathrm{C}(\mathrm{CHNS} / \mathrm{O})$ using an elementary analyzer (Perkin Elmer, PE-2400 Series II). In this method, a small soil sample is heated up to $900^{\circ} \mathrm{C}$ and the $\mathrm{CO}_{2}$ resulting from the material's combustion is measured. The results are expressed as a percentage and refer to organic and inorganic carbon in the samples [28]. For each 10 samples, the apparatus was calibrated with standard-samples-cystine, for a total of 168 measurements.

\subsection{Carbon Stock Calculations}

The stock of organic carbon in the soil was quantified in a volumetric base usually expressed in $\mathrm{mg} \mathrm{C} \mathrm{ha}{ }^{-1}$ for layers $0-5 \mathrm{~cm}, 5-10 \mathrm{~cm}, 10-20 \mathrm{~cm}, 20-30 \mathrm{~cm}, 30-40 \mathrm{~cm}$ and $50-60 \mathrm{~cm}$ deep. The calculation of the stock of carbon for a determined depth $(\rho, \mathrm{cm})$ was made in the following way:

$$
S C=C \cdot \rho \cdot e / 10
$$

where:

$S C=$ stock of organic $\mathrm{C}$ in a determined depth $\left(\mathrm{Mg} \cdot \mathrm{ha}^{-1}\right)$

$C=$ level of total organic $\mathrm{C}$ in the sampled depth $\left(\mathrm{g} \cdot \mathrm{kg}^{-1}\right)$

$\rho=$ bulk density of the depth's soil $\left(\mathrm{kg} \cdot \mathrm{dm}^{-3}\right)$

$e=$ thickness of the analyzed layer $(\mathrm{cm})$

For each one of the six Humid Grassland areas sampled, we estimated the stocks of carbon in the soil until a depth of $60 \mathrm{~cm}$. We considered total stock values as the average value in the depths described, i.e. $0-5 \mathrm{~cm}, 5$ $10 \mathrm{~cm}, 10-20 \mathrm{~cm}, 20-30 \mathrm{~cm}, 30-40 \mathrm{~cm}, 40-50 \mathrm{~cm}$ and $50-60 \mathrm{~cm}$ deep. We multiplied the average value of carbon by the area occupied for the final calculation on the estimates of carbon stock in this ecosystem.

\section{Results}

The soil samples analyzed displayed distinct textural characteristics. Gleysols showed equivalent portions of sand $(32.37 \% \pm 3.66 \%)$, clay $(33.51 \% \pm 2.36 \%)$ and silt $(39.27 \% \pm 1.62 \%)$, while plinthosols showed a larger portion of clay $(46.54 \% \pm 1.33 \%)$ and silt $(39.27 \% \pm 1.62 \%)$ than of sand $(14.19 \% \pm 0.68 \%)$ (Table 2). This difference remained constant through the entire profile of sand particles. Gleysols had a predominantly claysand-loam texture, while plinthosols had a predominantly clay-silt texture.

The density did not differ among the soils in the profile $\left(0.75 \pm 0.05 \mathrm{~kg} \cdot \mathrm{dm}^{-3}\right.$ for gleysols and $0.72 \pm 0.03$ 
Table 2. Textural and physical aspects of gleysols and plinthosols in the study area, plus the average values obtained for Humid Grasslands areas (average \pm standard error).

\begin{tabular}{ccccc}
\hline Soil Type/Depth & Sand (\%) & Clay $(\%)$ & Silt $(\%)$ & Bulk Density $\left(\mathrm{kg} \cdot \mathrm{dm}^{-3}\right)$ \\
\hline Gleysols & $\mathbf{3 2 . 3 7} \pm \mathbf{3 . 6 6}$ & $\mathbf{3 3 . 5 1} \pm \mathbf{2 . 3 6}$ & $\mathbf{3 4 . 1 2} \pm \mathbf{2 . 5 6}$ & $\mathbf{0 . 7 5} \pm \mathbf{0 . 0 5}$ \\
$0-5 \mathrm{~cm}$ & $33.08 \pm 9.42$ & $34.83 \pm 6.23$ & $32.08 \pm 5.58$ & $0.55 \pm 0.13$ \\
$5-10 \mathrm{~cm}$ & $32.08 \pm 9.69$ & $31.42 \pm 6.14$ & $36.50 \pm 6.63$ & $0.60 \pm 0.12$ \\
$10-20 \mathrm{~cm}$ & $33.67 \pm 9.61$ & $28.50 \pm 5.32$ & $37.83 \pm 6.94$ & $0.68 \pm 0.12$ \\
$20-30 \mathrm{~cm}$ & $32.00 \pm 10.04$ & $32.92 \pm 6.39$ & $35.08 \pm 7.34$ & $0.76 \pm 0.12$ \\
$30-40 \mathrm{~cm}$ & $31.75 \pm 10.40$ & $33.92 \pm 6.62$ & $34.33 \pm 7.34$ & $0.80 \pm 0.12$ \\
$40-50 \mathrm{~cm}$ & $31.92 \pm 10.60$ & $35.67 \pm 6.85$ & $32.42 \pm 7.39$ & $0.90 \pm 0.13$ \\
$50-60 \mathrm{~cm}$ & $32.08 \pm 10.45$ & $37.33 \pm 7.27$ & $30.58 \pm 7.59$ & $0.98 \pm 0.12$ \\
Plintosols & $\mathbf{1 4 . 1 9} \pm \mathbf{0 . 6 8}$ & $\mathbf{4 6 . 5 4} \pm \mathbf{1 . 3 3}$ & $\mathbf{3 9 . 2 7} \pm \mathbf{1 . 6 2}$ & $\mathbf{0 . 7 2} \pm \mathbf{0 . 0 3}$ \\
$0-5 \mathrm{~cm}$ & $10.50 \pm 1.68$ & $41.00 \pm 2.98$ & $48.50 \pm 4.26$ & $0.46 \pm 0.05$ \\
$5-10 \mathrm{~cm}$ & $11.92 \pm 1.93$ & $40.25 \pm 2.54$ & $47.83 \pm 4.15$ & $0.55 \pm 0.06$ \\
$10-20 \mathrm{~cm}$ & $15.25 \pm 2.00$ & $40.50 \pm 2.48$ & $44.25 \pm 3.59$ & $0.65 \pm 0.06$ \\
$20-30 \mathrm{~cm}$ & $15.17 \pm 1.72$ & $45.50 \pm 3.25$ & $39.33 \pm 4.37$ & $0.74 \pm 0.07$ \\
$30-40 \mathrm{~cm}$ & $16.58 \pm 1.79$ & $49.58 \pm 3.86$ & $33.83 \pm 4.03$ & $0.82 \pm 0.08$ \\
$40-50 \mathrm{~cm}$ & $14.42 \pm 1.56$ & $53.67 \pm 3.42$ & $31.92 \pm 3.74$ & $0.92 \pm 0.07$ \\
$50-60 \mathrm{~cm}$ & $15.50 \pm 1.70$ & $55.25 \pm 3.55$ & $29.25 \pm 2.88$ & $0.92 \pm 0.07$ \\
Humid Grasslands & $\mathbf{2 3 . 2 8} \pm \mathbf{1 . 4}$ & $\mathbf{4 0 . 0 2} \pm \mathbf{1 . 0 2}$ & $\mathbf{3 6 . 7} \pm \mathbf{1 . 0 8}$ & $\mathbf{0 . 7 4} \pm \mathbf{0 . 0 2}$ \\
\hline
\end{tabular}

$\mathrm{kg} \cdot \mathrm{dm}^{-3}$ for plinthosols). Density grew for both soils, with minimum values for the more superficial depth of 0 $5 \mathrm{~cm}\left(0.55 \pm 0.13 \mathrm{~kg} \cdot \mathrm{dm}^{-3}\right.$ for gleysols and $0.46 \pm 0.05 \mathrm{~kg} \cdot \mathrm{dm}^{-3}$ for plinthosols $)$ and maximum values for the depth of $50-60 \mathrm{~cm}\left(0.98 \pm 0.12 \mathrm{~kg} \cdot \mathrm{dm}^{-3}\right.$ for gleysols and $0.92 \pm 0.07 \mathrm{~kg} \mathrm{dm}^{-3}$ for plinthosols $)$. We observed the biggest difference between the soils, although not significant, for the more superficial depth $0-5 \mathrm{~cm}$ (Figure 3).

The average concentration of carbon for Humid Grassland areas was $55.19 \pm 2.30 \mathrm{~g} \cdot \mathrm{kg}^{-1}$, with an average $61.65 \pm 5.21 \mathrm{~g} \cdot \mathrm{kg}^{-1}$ for gleysols areas and $48.73 \pm 3.81 \mathrm{~g} \cdot \mathrm{kg}^{-1}$ for plinthosols areas (Table 3). The concentration of carbon decreased with the depth, with plinthosols showing progressively smaller concentrations throughout the entire profile (Figure 4).

The average concentration of nitrogen for Humid Grassland areas was $20.66 \pm 1.07 \mathrm{~g} \cdot \mathrm{kg}^{-1}$, with concentration values decreasing with the depth (Table 3). Although the average concentration of nitrogen in the soil was higher in gleysols, plinthosols displayed higher values for the more superficial depth $(0-5 \mathrm{~cm}): 25.04 \pm 6.05$ $\mathrm{g} \cdot \mathrm{kg}^{-1}$ for gleysols and $27.65 \pm 4.48 \mathrm{~g} \cdot \mathrm{kg}^{-1}$ for plinthosols (Figure 4).

The average carbon storage for Humid Grasslands was $244.17 \pm 16.86 \mathrm{mg} \mathrm{C} \mathrm{ha}^{-1}$ and the total storage estimated for these areas in the Federal District was $206.71 \pm 14.27 \mathrm{Gg} \cdot \mathrm{C}$.

In all layers of the analyzed profile, gleysol samples showed higher stock levels of carbon than plinthosols. Throughout the entire profile $(0-60 \mathrm{~cm})$, gleysols showed values of $278.08 \pm 41.34 \mathrm{mg} \mathrm{C} \mathrm{ha}^{-1}$, while plinthosols showed values of $211.38 \pm 25.5 \mathrm{mg} \mathrm{Cha}^{-1}$. The values for carbon storage reached their maximum at the more superficial depth $(0-10 \mathrm{~cm})$ of gleysols $\left(47.59 \pm 17.65 \mathrm{mg} \mathrm{C}^{-1}\right)$ and the minimum at $50-60 \mathrm{~cm}(34.56$ $\left.\pm 14.78 \mathrm{mg} \mathrm{C} \mathrm{ha}^{-1}\right)$. Similarly for plinthosols, the maximum values were obtained at the first $10 \mathrm{~cm}(37.69 \pm$ $\left.7.13 \mathrm{mg} \mathrm{C} \mathrm{ha}^{-1}\right)$ and the minimum between 50-60 $\mathrm{cm}\left(21.69 \pm 5.89 \mathrm{mg} \mathrm{Cha}^{-1}\right.$ ) (Figure 5).

Cumulative values for depth classes $(0-5 \mathrm{~cm} ; 0-10 \mathrm{~cm} ; 0-20 \mathrm{~cm} ; 0-30 \mathrm{~cm} ; 0-40 \mathrm{~cm} ; 0-50 \mathrm{~cm}$ and 0 $60 \mathrm{~cm}$ ) showed almost constant rates for the variation of carbon storage as a function of the depth. The rate, given as mega grams carbon per hectare per depth centimeter $\left(\mathrm{mg} \mathrm{C} \mathrm{ha}{ }^{-1} \cdot \mathrm{cm}^{-1}\right)$, was $4.65 \mathrm{mg} \mathrm{Cha}{ }^{-1} \cdot \mathrm{cm}^{-1}$ in gleysols and $3.55 \mathrm{mg} \mathrm{C} \mathrm{ha}{ }^{-1} \cdot \mathrm{cm}^{-1}$ in plinthosols (Figure 5). 


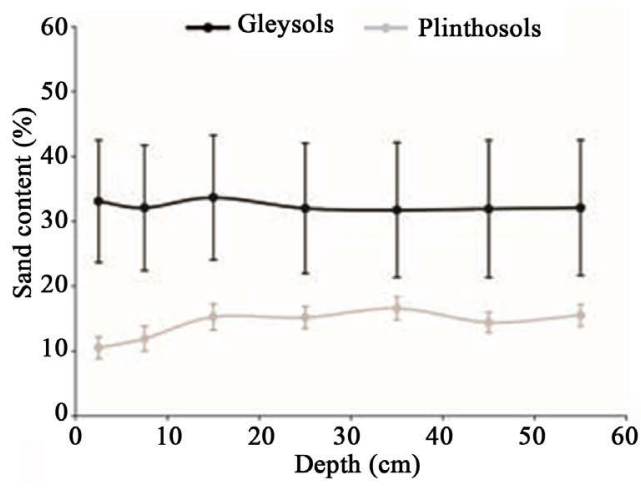

(a)

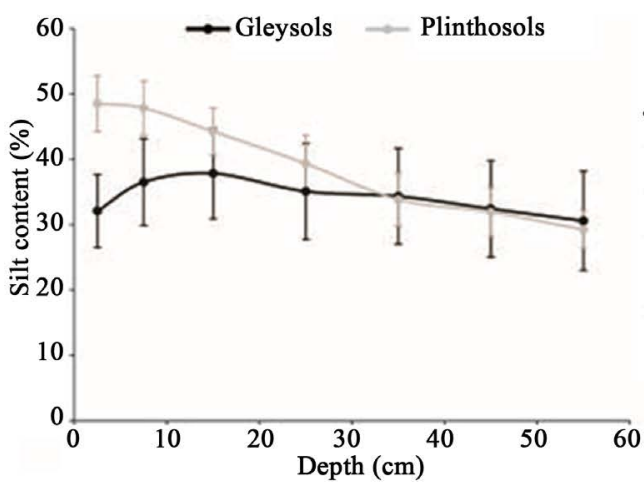

(c)

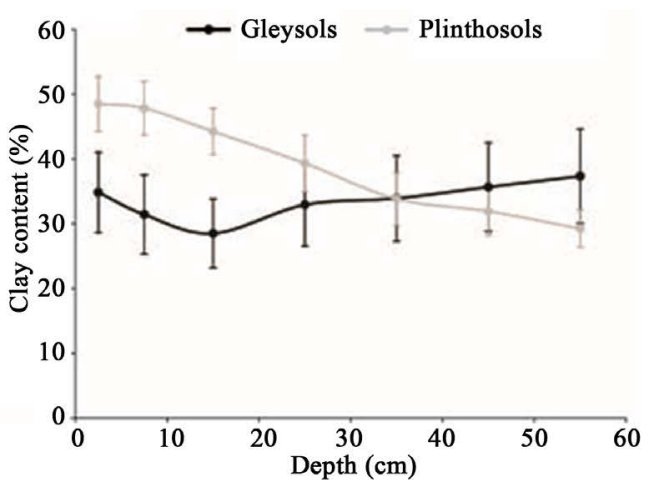

(b)

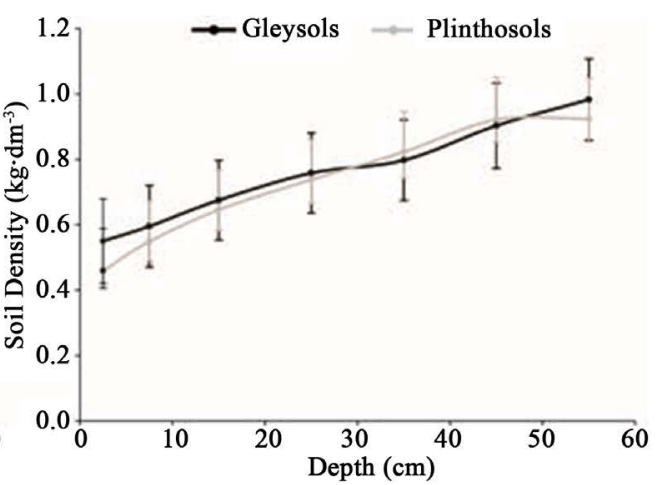

(d)

Figure 3. Proportion of sand (a), clay (b), silt (c), and soil density (d) throughout the profile in gleysols (black) and plinthosols (grey).

Table 3. Values obtained for carbon and nitrogen storage in different portions of the analysed profile (average \pm standard error).

\begin{tabular}{|c|c|c|c|c|c|c|}
\hline Soil Type/Depth & $\mathrm{N}$ & $\begin{array}{l}\text { Depth Range } \\
\quad(\mathrm{cm})\end{array}$ & $\begin{array}{l}\text { Nitrogen } \\
\left(\mathrm{g} \cdot \mathrm{kg}^{-1}\right)\end{array}$ & $\begin{array}{l}\text { Carbon } \\
\left(\mathrm{g} \cdot \mathrm{kg}^{-1}\right)\end{array}$ & $\begin{array}{l}\text { Carbon Stock } \\
\left(\mathrm{mg} \mathrm{C} \mathrm{ha}^{-1}\right)\end{array}$ & $\begin{array}{l}\text { Accumulated Carbon } \\
\text { Stock }\left(\mathrm{mg} \mathrm{C} \mathrm{ha}^{-1}\right)^{*}\end{array}$ \\
\hline Gleysols & 84 & 60 & $23.98 \pm 2.61$ & $61.65 \pm 5.21$ & $278.08 \pm 41.34$ & $278.08 \pm 41.34$ \\
\hline $0-5 \mathrm{~cm}$ & 12 & 5 & $25.04 \pm 6.05$ & $87.49 \pm 15.96$ & $24.08 \pm 10.03$ & $24.08 \pm 10.03$ \\
\hline $5-10 \mathrm{~cm}$ & 12 & 5 & $26.56 \pm 6.89$ & $79.08 \pm 14.73$ & $23.54 \pm 9.32$ & $47.71 \pm 13.43$ \\
\hline $10-20 \mathrm{~cm}$ & 12 & 10 & $28.06 \pm 7.58$ & $70.48 \pm 13.41$ & $47.59 \pm 17.65$ & $95.92 \pm 21.31$ \\
\hline $20-30 \mathrm{~cm}$ & 12 & 10 & $25.72 \pm 7.43$ & $59.72 \pm 12.48$ & $45.27 \pm 16.77$ & $143.51 \pm 27.26$ \\
\hline $30-40 \mathrm{~cm}$ & 12 & 10 & $24.88 \pm 7.49$ & $55.22 \pm 13.39$ & $44.03 \pm 17.46$ & $190.15 \pm 32.40$ \\
\hline $40-50 \mathrm{~cm}$ & 12 & 10 & $19.87 \pm 6.96$ & $44.41 \pm 11.92$ & $40.10 \pm 16.56$ & $235.60 \pm 37.17$ \\
\hline $50-60 \mathrm{~cm}$ & 12 & 10 & $17.76 \pm 7.19$ & $35.16 \pm 10.59$ & $34.56 \pm 14.78$ & $278.08 \pm 41.34$ \\
\hline Plinthosols & 84 & 60 & $17.34 \pm 1.45$ & $48.73 \pm 3.81$ & $211.38 \pm 25.50$ & $211.38 \pm 25.50$ \\
\hline $0-5 \mathrm{~cm}$ & 12 & 5 & $27.65 \pm 4.48$ & $79.84 \pm 13.00$ & $18.34 \pm 5.13$ & $18.34 \pm 5.13$ \\
\hline $5-10 \mathrm{~cm}$ & 12 & 5 & $27.03 \pm 5.10$ & $69.70 \pm 10.24$ & $19.12 \pm 4.89$ & $37.69 \pm 7.13$ \\
\hline $10-20 \mathrm{~cm}$ & 12 & 10 & $20.97 \pm 3.57$ & $57.13 \pm 8.63$ & $36.88 \pm 9.19$ & $75.96 \pm 11.77$ \\
\hline $20-30 \mathrm{~cm}$ & 12 & 10 & $15.48 \pm 2.91$ & $45.99 \pm 8.21$ & $33.94 \pm 9.44$ & $113.31 \pm 15.90$ \\
\hline $30-40 \mathrm{~cm}$ & 12 & 10 & $11.98 \pm 2.30$ & $36.69 \pm 7.27$ & $30.19 \pm 8.93$ & $148.83 \pm 19.68$ \\
\hline $40-50 \mathrm{~cm}$ & 12 & 10 & $9.46 \pm 1.61$ & $28.32 \pm 5.66$ & $26.10 \pm 7.17$ & $182.50 \pm 22.98$ \\
\hline $50-60 \mathrm{~cm}$ & 12 & 10 & $8.84 \pm 1.39$ & $23.48 \pm 4.58$ & $21.69 \pm 5.89$ & $211.38 \pm 25.5$ \\
\hline Humid Grasslands & 168 & 60 & $20.66 \pm 1.07$ & $55.19 \pm 2.30$ & $244.17 \pm 16.86$ & $244.17 \pm 16.86$ \\
\hline
\end{tabular}




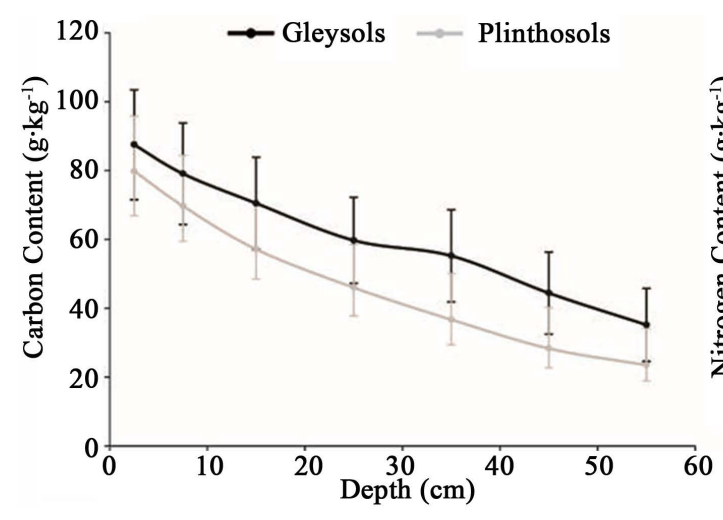

(a)

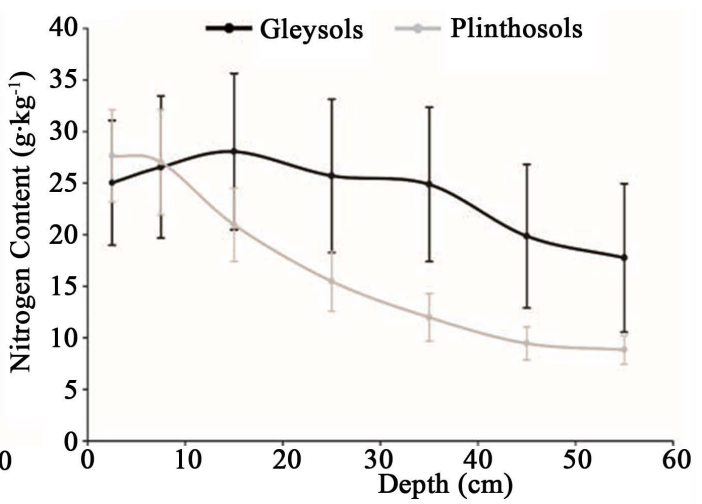

(b)

Figure 4. Level of carbon (a) and nitrogen (b) through the profile in gleysols (black) and plinthosols (grey).

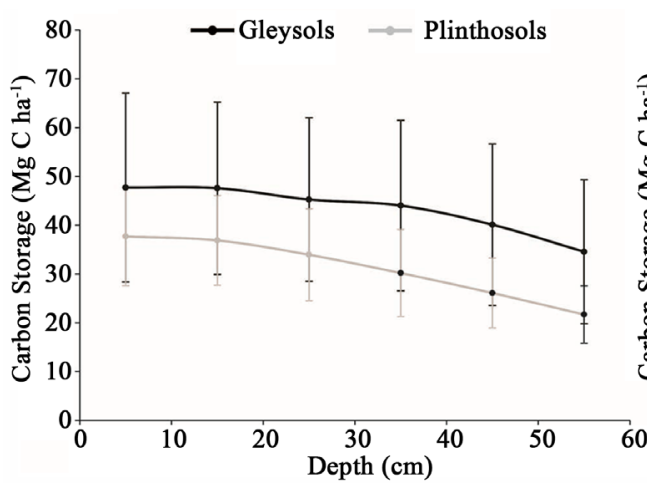

(a)

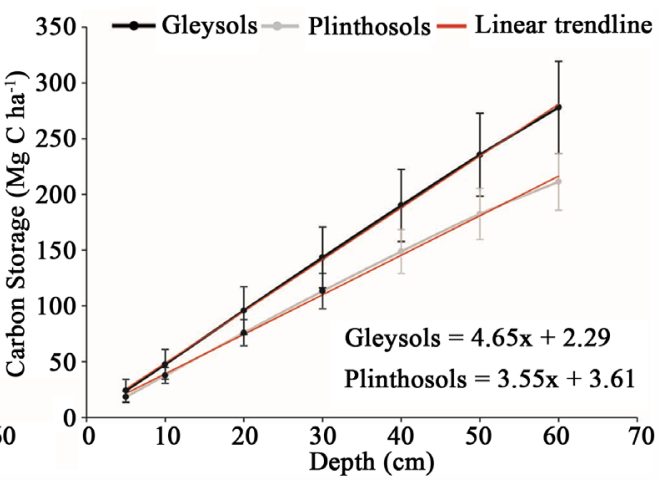

(b)

Figure 5. Carbon storage for each depth intervals of $0-10 \mathrm{~cm}, 10-20 \mathrm{~cm}, 20-30 \mathrm{~cm}, 30-40 \mathrm{~cm}, 40$ $50 \mathrm{~cm}$ and $50-60 \mathrm{~cm}$ (a); cumulative carbon storage throughout the profile $(0-60 \mathrm{~cm})$ and the linear trendlines (red lines) (b) in gleysols (black) and plinthosols (grey).

\section{Discussion}

Wetlands areas in the tropical region are recognizably important natural carbon sinks [6] [8] [29] [30]. Although very little research exists currently about carbon stock levels in Cerrado wetlands, the results obtained from this study confirm the positive role that this vegetation can play in maintaining soil carbon storage.

The soil density in Humid Grassland areas proved superior to that observed in other more well-drained areas of the Cerrado (Table 4). In savanna areas (Cerrado sensu stricto) the carbon stocks were estimated between 45 $\mathrm{mg} \mathrm{C} \mathrm{ha}{ }^{-1}$ and $73 \mathrm{mg} \mathrm{Cha}^{-1}$ for depths down to $60 \mathrm{~cm}$, a value 5 times smaller than the storage density obtained for the wetland areas analyzed.

In grassland formations, existing in well-drained regions (with Ferrasol soils), the density of carbon storage was also inferior to that obtained from Humid Grassland areas (Table 4). Despite the similarity of vegetation between these regions, clear fields had the stock of soil estimated in $100 \mathrm{mg} \mathrm{C} \mathrm{ha}^{-1}$ for the depth of until $100 \mathrm{~cm}$ [31], less than half of that observed in Humid Grasslands areas.

The average carbon storage levels obtained in this study confirm those observed by [38], which quantified carbon stocks in a single Humid Grassland area in the Federal District (Table 4). That study was done using the method of oxidation through wet process [39]. In it, the carbon stock was estimated at $241 \mathrm{Mg} \cdot \mathrm{ha}^{-1}$ to $60 \mathrm{~cm}$ deep, while in the current study, which was conducted using the dry combustion analytic method and included 6 Humid Grassland areas, the carbon stock was estimated in $244.17 \mathrm{mg} \mathrm{C} \mathrm{ha}^{-1}$ (Standard Error $16.86 \mathrm{mg} \mathrm{C} \mathrm{ha}{ }^{-1}$ ) to $60 \mathrm{~cm}$ deep.

The results obtained suggest a possible difference in the density of carbon storage levels between Humid Grass-land areas for gleysols and plinthosols. In general, the samples obtained for gleysols showed levels of carbon and nitrogen superior to those of plinthosols. In addition, for all the compounds analyzed (sand, clay, silt, 
Table 4. Estimates for the density of carbon storages in the soil for different vegetation of the Cerrado biome.

\begin{tabular}{ccccccc}
\hline \multirow{2}{*}{ Vegetation Type } & Cerrado Type & Soil Type (FAO) & \multicolumn{3}{c}{ Carbon Stock $\left(\mathrm{mg} \mathrm{C} \mathrm{ha}^{-1}\right)$} & References \\
\cline { 3 - 5 } High savannah & Cerradão & Ferralsols & - & 148 & 230 & {$[32]$} \\
Typical savannah & Cerrado & Ferralsols & - & 143 & 231 & {$[32]$} \\
Typical savannah & Cerrado & Ferralsols & - & 133 & - & {$[33]$} \\
Typical savannah & Cerrado & Ferralsols & 45 & - & - & {$[34]$} \\
Typical savannah & Cerrado & Cambisols & - & 200 & - & {$[35]$} \\
Typical savannah & Cerrado sensu stricto & Ferralsols & - & & 271 & {$[36]$} \\
Typical savannah & Cerrado sensu stricto & Regosols & 50 & - & - & {$[37]$} \\
Typical savannah & Cerrado sensu stricto & Ferralsols & 74 & - & - & {$[37]$} \\
Shrubland & Campo Sujo & Ferralsols & - & 209 & 297 & {$[32]$} \\
Grassland & Campo Limpo & Ferralsols & - & 198 & 281 & {$[32]$} \\
Grassland & Campo Limpo & Ferralsols & - & 100 & - & {$[31]$} \\
Grassland & Campo Limpo Úmido & Histosols & 241 & - & - & {$[38]$} \\
\hline
\end{tabular}

soil density, nitrogen and carbon), a higher variability was observed for samples obtained in gleysols, with the variation of carbon storage around $10 \%$ higher in this soil than among plinthosol samples. Although the results obtained in this study suggest a possible difference in the carbon stock levels of Humid Grassland areas based on soil type, a greater sampling effort is needed for the confirmation of such difference.

Changes to the use and handling of wetland areas, from a natural state to made for human use, have been widely recognized as factors contributing to the emission of carbon from the soil into the atmosphere [6] [7]. In areas of the Cerrado biome the variations in carbon stock levels, after the conversion from native areas to anthropic areas, depend especially on the types of native vegetation present, kinds of soil, local rainfall and handling practices [40]. Existed studies report both an increase (e.g. [41]) and reduction in the carbon stocks based on these factors (e.g. [42]).

All the Cerrado biomes natural regions have suffered annually with the conversion of $7652 \mathrm{~km}^{2}$ of its area, primarily for agricultural use or animal husbandry [14]. Considering just the Federal District area $(0.3 \%$ of the total area of the Cerrado Biome) we observed in this study total carbon storage, to $60 \mathrm{~cm}$ deep in Humid Grassland areas, of $206.71 \pm 14.27 \mathrm{Gg} \cdot \mathrm{C}$. The continuity of the anthropization of natural habitats has the potential to promote the liberation of expressive quantities of carbon into the atmosphere on this kind of Cerrado phytophysiognomies. Therefore, it is recommended that specific studies are conducted to further investigate variations in the carbon stock levels resulting from changes in use and handling of Humid Grassland regions, as well as re-search that covers the entire area of Cerrado.

\section{Conclusion}

The results show that Humid Grasslands, one type of vegetation found in the Cerrado biome, have a high potential to store carbon in the soil, with an estimate of $244.17 \mathrm{mg} \mathrm{C} \mathrm{ha}^{-1}$ (Standard error $16.86 \mathrm{mg} \mathrm{C} \mathrm{ha}^{-1}$ ) until a depth of $60 \mathrm{~cm}$. The total stock estimated for these areas in the Federal District was $206.71 \pm 14.27 \mathrm{Gg} \cdot \mathrm{C}$, in 846.61 ha of Humid Grassland areas mapped by [22]. The results obtained suggest a possible difference between the studied areas, observing the presence of gleysols and plinthosols. The first type of soil shows values of $278.08 \pm 41.34 \mathrm{mg} \mathrm{C} \mathrm{ha}^{-1}$, while plinthosols show values of $21.38 \pm 25.5 \mathrm{mg} \mathrm{C} \mathrm{ha}^{-1}$. Despite these findings, a greater sampling effort is needed to confirm the differences between carbon stocks for both soil types. Considering the great anthropic pressure to which the Cerrado's natural regions are subjected, it is recommended that further specific studies are conducted, investigating variations in the carbon stock levels resulting from changes in use and handling of Humid Grassland regions, as well as research that covers the entire area of the biome. 


\section{References}

[1] IPCC (2013) Climate Change 2013: The Physical Science Basis. Contribution of Working Group I to the 5th Assessment Report of the Intergovernmental Panel on Climate Change. Cambridge University Press, Cambridge and New York, 467-544.

[2] Lal, R. and Follett, R.F. (2009) Soil Carbon Sequestration and the Greenhouse Effect. Soil Science Society of America, Madison.

[3] Lal, R. (2004) Soil Carbon Sequestration to Mitigate Climate Change. Geoderma, 123, 1-22. http://dx.doi.org/10.1016/j.geoderma.2004.01.032

[4] Smith, K.A.S, Ball, T.B., Conen, F.C., Dobbie, K.E.D., Massheder, J.M., et al. (2003) Exchange of Greenhouse Gases between Soil and Atmosphere: Interactions of Soil Physical Factors and Biological Processes. European Journal of Soil Science, 54, 779-791. http://dx.doi.org/10.1046/j.1351-0754.2003.0567.x

[5] Coletti, J.Z., Hinz, C., Vogwill, R. and Hipsey, M.R. (2013) Hydrological Controls on Carbon Metabolism in Wetlands. Ecological Modelling, 249, 3-18. http://dx.doi.org/10.1016/j.ecolmodel.2012.07.010

[6] Neue, H.U., Gaunt, J.L., Wang, Z.P., Becker-Heidmann, P. and Quijano, C. (1997) Carbon in Tropical Wetlands. Geoderma, 1, 163-185. http://dx.doi.org/10.1016/S0016-7061(97)00041-4

[7] Mitra, S., Wassmann, R. and Vlek, P.L.G. (2005) An Appraisal of Global Wetland Area and Its Organic Carbon Stock. Current Science, 88, 25-35.

[8] De La Cruz, A.A. (1986) Tropical Wetlands as a Carbonsource. Aquatic Botany, 25, 109-115. http://dx.doi.org/10.1016/0304-3770(86)90048-3

[9] IBAMA (2011) Relatorio Técnico de monitoramento do desmatamento no Bioma Cerrado, 2009 a 2010. Relatório Técnico, IBAMA, Brasília. http://siscom.ibama.gov.br/

[10] IBAMA (2011) Relatorio Técnico de monitoramento do desmatamento no Bioma Cerrado, 2008 a 2009. Relatório Técnico IBAMA, Brasília. http://siscom.ibama.gov.br/

[11] IBAMA (2009) Relatorio Técnico de monitoramento do desmatamento no Bioma Cerrado, 2002 a 2008: Dados Revisados. Relatório Técnico, IBAMA, Brasília. http://siscom.ibama.gov.br/

[12] Rocha, G.F., Ferreira, L.G., Ferreira, N.C. and Ferreira, M.E. (2011) Detecção de desmatamentos no Bioma Cerrado entre 2002 e 2009: Padrões, Tendências e Impactos. Revista Brasileira de Cartografia, 63, 341-349.

[13] MMA (2011) Plano de Ação para Prevenção e Controle do Desmatamento e das Queimadas-Cerrado. Ministério do Meio Ambiente, Brasília.

[14] Soares-filho, B., Rajão, R., Macedo, M., Carneiro, A., Costa, W., et al. (2014) Cracking Brazil's Forest Code. Science, 344, 363-364. http://dx.doi.org/10.1126/science.1246663

[15] Walter, B.M.T., Carvalho, A.M. and Ribeiro, J.F. (2008) O Conceito de Savana e de seu Componente Cerrado. In: Sano, S.M., Almeida, S.P. and Ribeiro, J.F., Eds., Cerrado: Ecologia e Flora, Embrapa Informação Tecnológica, Brasília, 19-45.

[16] Ribeiro, J.F. and Walter, B.M.T. (1998) Fitofisionomias do bioma cerrado. In: Sano, S.M. and Almeida, S.P., Eds., Cerrado: Ambiente e Flora, Embrapa-CPAC, Brasília, 89-166.

[17] Munhoz, C.B.R. and Felfili, J.M. (2008) Fitossociologia do estrato herbáceo-subarbustivo em campo limpo úmido no Brasil Central. Acta Botanica Brasilica, 22, 905-913. http://dx.doi.org/10.1590/S0102-33062008000400002

[18] IBGE (2004) Mapa de Biomas do Brasil. IBGE, Brasília. http://www.ibge.gov.br/

[19] Silva, J.F., Fariñas, M.R., Felfili, J.M. and Klink, C.A. (2006) Spatial Heterogeneity, Land Use and Conservation in the Cerrado Region of Brazil. Journal of Biogeography, 33, 536-548. http://dx.doi.org/10.1111/j.1365-2699.2005.01422.x

[20] Klink, C.A. and Machado, R.B. (2005) Conservation of the Brazilian Cerrado. Conservation Biology, 19, $707-713$. http://dx.doi.org/10.1111/j.1523-1739.2005.00702.x

[21] Eiten, G. (1972) The Cerrado Vegetation of Brazil. The Botanical Review, 38, 201-327. http://dx.doi.org/10.1007/BF02859158

[22] França, A.M.S. and Sano, E.E. (2011) Mapeamento de áreas de campo limpo úmido no Distrito Federal a partir de fusão de imagens multiespectrais. Sociedade e Natureza, 2, 197-209.

[23] Food and Agriculture Organization (2006) World Reference Base for Soil Resources 2006: A Framework for International Classification, Correlation And Communication. FAO, Rome.

[24] Reatto, A., Spera, S.T., Correia, J.R., Martins, S. and Milhomen, A. (1998) Solos de ocorrência em duas áreas sob matas de galeria no Distrito Federal: Aspectos pedológicos, uma abordagem química e físico-hídrica. In: Ribeiro, J.F., Fonseca, C.E.L. and Sousa-Silva, J.C., Eds., Cerrado: Caracterização e recuperação de matas de galeria, Embrapa Cerrados, Brasília, 115-140. 
[25] Embrapa (2006) Sistema Brasileiro de Classificação de Solos. Embrapa-SPI, Rio de Janeiro.

[26] Lepsch, I.F. (2002) Formação e Conservação Dos Solos. Oficina de Textos, São Paulo.

[27] Oliveira, J.B., Jacomine, P.K.T. and Camargo, M.N. (1992) Classes Gerais de Solos do Brasil. Guia Auxiliar para seu Reconhecimento. FUNEP, Jaboticabal-SP.

[28] Skjemstad, J. and Baldock, J.A (2007) Total and Organic Carbon. In: Carter, M.E. and Gregorich, E.G. Eds., Soil Sampling and Methods of Analysis, 2nd Edition, Soil Science Society of Canada, Boca Raton, 225-238.

[29] Bernal, B. and Mitsch, W.J. (2008) A Comparison of Soil Carbon Pools and Profiles in Wetlands in Costa Rica and Ohio. Ecological Engineering, 4, 311-323. http://dx.doi.org/10.1016/j.ecoleng.2008.09.005

[30] Bianchi, T.S., Allison, M.A., Zhao, J., Li, X., Comeaux, R.S., et al. (2013) Estuarine, Coastal and Shelf Science Historical Reconstruction of Mangrove Expansion in the Gulf of Mexico: Linking Climate Change with Carbon Sequestration in Coastal Wetlands. Estuarine, Coastal and Shelf Science, 119, 7-16. http://dx.doi.org/10.1016/j.ecss.2012.12.007

[31] Silva, J.E., Resck, D.V.S., Corazza, E.J. and Vivaldi, L. (2004) Carbon Storage in Clayey Oxisol Cultivated Pastures in the Cerrado Region, Brazil. Agriculture, Ecosystems \& Environment, 103, 357-363. http://dx.doi.org/10.1016/j.agee.2003.12.007

[32] Lardy, L.C., Brossard, M., Assad, M.L.L. and Laurent, J.Y. (2002) Carbon and Phosphorus Stocks of Clayey Ferralsols in Cerrado Native and Agroecosystems, Brazil. Agriculture, Ecosystems \& Environment, 92, 147-158. http://dx.doi.org/10.1016/S0167-8809(01)00303-6

[33] Corazza, E.J., Silva, J.E., Resck, D.V.S. and Gomes, A.C. (1999) Comportamento de diferentes sistemas de manejo como fonte ou depósito de carbono em relação à vegetação de Cerrado. Revista Brasileira de Ciências do Solo, 23, 425-432.

[34] Resck, B.S., Resck, D.V.S., Ferreira, E.A.B. and Gomes, A.C. (2008) Estoque de carbono do solo sob diferentes sistemas de manejo na bacia hidrográfica do córrego taquara, Distrito Federal. II Simpósio Internacional Savanas Tropicais, 1-6.

[35] Silva, L.C.R, Sternberg, L., Haridasan, M., Hoffmann, W.A., Miralles-Wilhelm, F. and Franco, A.C. (2008) Expansion of Gallery Forests into Central Brazilian Savannas. Global Change Biology, 14, 2108-2118. http://dx.doi.org/10.1111/j.1365-2486.2008.01637.x

[36] Paiva, A.O. and Faria, G.E. (2007) Evaluation of the Soil Carbon Stock in a cerrado sensu stricto at Federal. Revista Trópica, 1, 59-65.

[37] Zinn, Y.L., Resck, D.V.S. and Silva, J.E. (2002) Soil Organic Carbon as Affected by Afforestation with Eucalyptus and Pinus in the Cerrado Region of Brazil. Forest Ecologyand Management, 166, 285-294. http://dx.doi.org/10.1016/S0378-1127(01)00682-X

[38] Meirelles, M.L., Ferreira, E.A.B. and Franco, A.C. (2006) Dinâmica Sazonal do Carbono em Campo Úmido do Cerrado. Documentos/Embrapa Cerrados, 164, 32 p.

[39] Walkley, A. and Black, I.A. (1934) An Examination of the Determining Method for Determining Soil Organic Matter and a Proposed Modification of the Chromic Acid Titration Method. Soil Science, 37, 29-38. http://dx.doi.org/10.1097/00010694-193401000-00003

[40] Batlle-bayer, L., Batjes, N.H. and Bindraban, P.S. (2010) Agriculture, Ecosystems and Environment Changes in Organic Carbon Stocks upon Land Use Conversion in the Brazilian Cerrado: A Review. Agriculture, Ecosystems \& Environment, 137, 47-58. http://dx.doi.org/10.1016/j.agee.2010.02.003

[41] Marchão, R.L., Becquer, T., Brunet, D., Balbino, L.C., Vilela, L., et al. (2009) Carbon and Nitrogen Stocks in a Brazilian Clayey Oxisol: 13-Year Effects of Integrated Crop-Livestock Management Systems. Soil and Tillage Research, 103, 442-450. http://dx.doi.org/10.1016/j.still.2008.11.002

[42] Balieiro, F.C., Prado, R.B., Coutinho, H.L.C., Benites, V.M., Fidalgo, E.C.C., et al. (2010) Soil Carbon Stocks in Southwest Goiás, Brazilian Cerrado: Land Use Impact and Spatial Distribution. Proceedings of 19th World Congress of Soil Science, Soil Solutions for a Changing World, Brisbane, 6 August 2010, 2008-2011. 
Scientific Research Publishing (SCIRP) is one of the largest Open Access journal publishers. It is currently publishing more than 200 open access, online, peer-reviewed journals covering a wide range of academic disciplines. SCIRP serves the worldwide academic communities and contributes to the progress and application of science with its publication.

Other selected journals from SCIRP are listed as below. Submit your manuscript to us via either submit@scirp.org or Online Submission Portal.
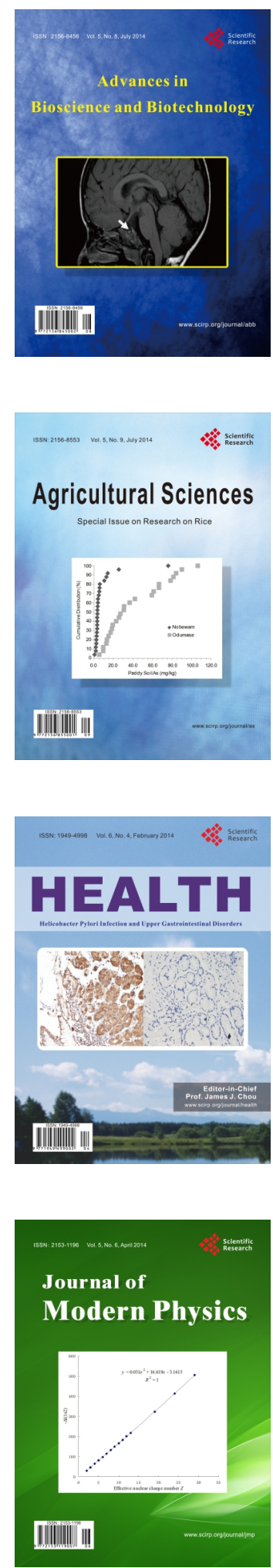
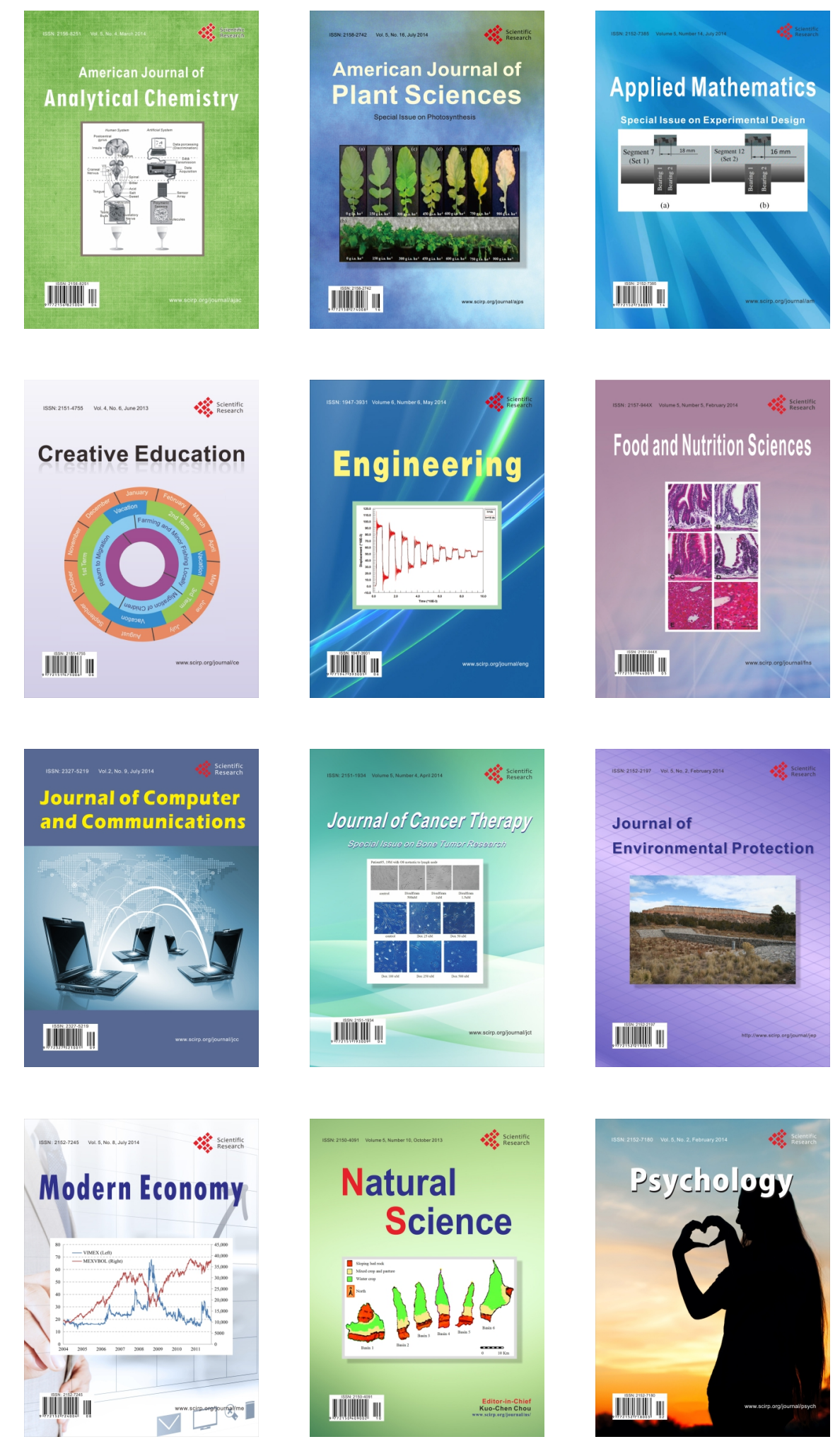